\title{
Phytochemical screening and galactagogic attributes of Pergularia daemia (Forssk.) Chiov. leaf extract in lactating mice (Mus musculus)
}

\author{
MONOJ PATRA ${ }^{1}$, SANTOSH KUMAR GIRI ${ }^{1 \oplus}$, SUBHAS CHOWDHURY ${ }^{2}$, JAYEETA PAL ${ }^{1 \oplus}$, \\ NIMAI CHANDRA SAHA ${ }^{3 \oplus}$, SURJYO JYOTI BISWAS ${ }^{* 1 \odot}$
}

\author{
${ }^{1}$ Department of Zoology, \\ Sidho-Kanho-Birsha University, Purulia, PO: Sainik School, Ranchi Road, Purulia \\ West Bengal-723104, India \\ ${ }^{2}$ Laskarpur High School \\ Lalgola, Lalbagh, Murshidabad \\ West Bengal-742151, India \\ ${ }^{3}$ Department of Zoology \\ The University of Burdwan, Burdwan \\ West Bengal-713104, India \\ *corresponding author: phone: +91-9475260322; e-mail: surjyo@rediffmail.com
}

\section{Summary}

Introduction: Pergularia daemia (Forssk.) Chiov. [PD] is used as a galactagogue by various tribes in Purulia district, India, lacks a scientific basis.

Objectives: The purpose of the study was to determine whether administration of aqueous leaf extract of P. daemia can increase milk production in lactating mice and encourages development in suckling pups.

Methods: 30 lactating mice ( $n=6$ per group) with a minimum of 5 pups each were treated with the aqueous PD extract at 50,100, 150 and $200 \mathrm{mg} / \mathrm{kg}$ body weight while the control group was administered with only distilled water. The mice were daily fed with aqueous leaf extract via gavage, which started at day 3 and continued to day 15 post-partum and milk secretion was assessed by the weight-suckle-weight method. The qualitative estimation, UV-vis analysis and GC-MS study of the leaf extract was also done for the presence of phytoconstituents.

Results: Administration of aqueous leaf extract led to a considerable increase in milk production (28.1\%) and the pups gained weight substantially $(p<0.05)$ when compared to control. Milk production was enhanced in mice treated with $150 \mathrm{mg} / \mathrm{kg}$ b.wt. of leaf extract compared to other doses $(p<0.05)$. The GC-MS analysis of the aqueous leaf extract of $P$. daemia revealed 20 major peaks, some with small retention time and also revealing presence of several phyto-estrogenic compounds. 
Conclusion: The present study effectively demonstrated that aqueous leaf extract of PD enhanced milk production in mice and might be used as an alternative strategy for increasing milk production and can be extrapolated to farm animals and human beings.

Key words: GC-MS, hormones, lactation, phytochemicals, Pergularia daemia

Słowa kluczowe: GC-MS, hormony, laktacja, związki bioaktywne, Pergularia daemia

\section{INTRODUCTION}

Food intake, digestibility, stimulation of the immune system, and increasing milk yield are some of the criteria necessary for the development of the young. Due to endocrine anomalies and stress, milk production often decreases in lactating/nursing mothers $[1,2]$. There are numerous synthetic galactagogues but their efficacy was never tested. They are also not easily available to people of low socio-economic status and living in remote areas. Continuous milk supply is essential for neonatal growth. People believe that in addition to herbal galactagogues, consumption of watery foods and green vegetables increases lactation. Galactagogues are substances, foods, or herbal complements used to initiate, continue, or increase breast milk production. Currently, some herbal galactagogues have gained prominent acceptance in the scientific community as a substitute for allopathic drugs for increasing milk production [3-8]. Traditional folk use diverse parts of plants as galactagogues but they have not been validated. However, their use is still prevalent in many countries and are also commonly cultivated.

In India, the tribal people constitute about $8.6 \%$ of total population. These tribes live in small habitats in remote areas with no proper access to education and healthcare. They are considered to be the weakest segment in terms of socio-economic status with their socio-cultural pattern varying from tribe to tribe and from region to region. Purulia district of West Bengal is predominantly inhabited by tribal communities which include Santhals, Bhumij, Munda, Lodha, Kora, and Mahali. These tribal communities use various plant parts to increase milk production in farm animals. Tribal quacks usually administer them also to humans. Pergularia daemia (Forssk.) Chiov. is used as a galactagogue by various tribes but lacks scientific basis and has no literature available in various scientific databases. In such a set-up, there is a necessity to estimate its safety and efficiency as an herbal galactagogue.
Pergularia daemia (PD) belongs to the Asclepiadaceae family, vernacularly known as "Uttaravaruni" in Sanskrit, "Chagulbanti" in Bengali (locally), and "Utranajutuka" in Hindi. Several parts of PD were stated to have parasiticidal and antipyretic potential and often used for treatment of diarrhoea in infants and also intermittent fevers [9]. Furthermore, the aerial parts of $\mathrm{PD}$ have been reported for its various pharmacological properties: hepato-protective, antifertility, anti-diabetic, antimicrobial, anti-inflammatory, and wound healing potentials [10-15]. Other investigators reported the potential protective effect of this plant to counter snake bites and in the treatment of induced arthritis in experimental mice model [16, 17]. It was described by others that the shoots of $P D$ contain cardenolides, alkaloids, saponins, triterpenes and steroidal compounds $[18,19]$. However, after intensive examination of various biological databases (PubMed, Google Scholar) we did not encounter any articles that investigated the galactagogic property of the leaf extract of Pergularia daemia. Hence, the current investigation aimed to find the potential of aqueous leaf extracts of $\mathrm{PD}$ in promoting milk production in mice and to identify its phyto-constituents which were responsible for such effect.

\section{MATERIALS AND METHODS}

\section{Chemicals and reagents}

Concentrated $\mathrm{HCl}$, magnesium ribbon, concentrated $\mathrm{H}_{2} \mathrm{SO}_{4}$, ethanol, $\mathrm{NH}_{4} \mathrm{OH}, \mathrm{CHCl}_{3}$, ferric chloride, and $\mathrm{l}$-ascorbic acid were purchased from Merck (India) Ltd. Folin-Ciocalteau, glacial acetic acid, and methanol were procured from Merck, Germany. DPPH was obtained from Himedia, India. Gallic acid, sodium carbonate, and sodium bicarbonate were purchased from Sisco Research Laboratories, India. The prolactin assay kit was procured from Kruise Pathline, Ahmedabad, India. Entire chemicals, reagents and kits procured/used in the current investigation were of analytical grade. 


\section{Preparation of the leaf extract}

The plant parts were collected near the village of Ghatal, a flood prone area in West Bengal $\left(22.67^{\circ} \mathrm{N}\right.$, $87.72^{\circ} \mathrm{E}$ ), Midnapore district in September and October 2018, then they were identified. A plant specimen voucher was submitted to the Botany department (V256SKBU/2018) for the record. Sun dried leaves were extracted in Millipore grade water (the ratio of plant material to solvent was $1: 10 \mathrm{~m} / \mathrm{v}$. Extraction was conducted at room temperature $\left(25^{\circ} \mathrm{C}\right)$ and stirred constantly for 24 hours. The obtained extract's moisture was evaporated to a dry condition and stored at $4{ }^{\circ} \mathrm{C}$ till needed. The yield of the aerial part was $15.20 \%$ calculated by the equation:

$$
\text { yield }(\mathrm{g} / 100 \mathrm{~g} \text { dry plant leaf sample })=\mathrm{W} 1 \times 100 / \mathrm{W} 2,
$$

where W1 represents the mass of the extract after evaporation of the solvent and W2 was the mass of the dry plant sample, respectively.

\section{Preliminary phytochemical examination}

Phytochemical examination to find reduced sugars, flavonoids, tannins, alkaloids, carbohydrates, steroids, and glycosides was conducted by routine procedures described elsewhere [20].

\section{DPPH free radical scavenging activity of extract}

For the possession of the antioxidant properties of P. daemia extract, the methodology of Braca et al. was used, depending on radical scavenging properties of DPPH [21]. For diluting the working solution of the extract, ethanol was used, while ascorbic acid was used as a standard in various concentrations $(50,100$, 150, 200, 400, 600, $800 \mu \mathrm{g} / \mathrm{ml}) .0 .002 \%$ DPPH was dissolved in $\mathrm{C}_{2} \mathrm{H}_{5} \mathrm{OH}$ and $1 \mathrm{ml}$ of this was mixed to $1 \mathrm{ml}$ of working solution of the extract and the standard (ascorbic acid) separately, incubated for $45 \mathrm{~min}$ utes in the dark. The blank was made by mixing $1 \mathrm{ml}$ of $\mathrm{C}_{2} \mathrm{H}_{5} \mathrm{OH}$ with $1 \mathrm{ml}$ of $0.002 \%$ of DPPH, then the absorbance was documented at $517 \mathrm{~nm}$ (Shimadzu UV-1800) and \% inhibition was measured.

\section{Total phenolic content}

The method of Kim et al. with slight alterations was employed for estimation of total phenolic content of the aqueous leaf extract [22]. Briefly, $1 \mathrm{ml}$ of leaf extract was meticulously mixed with $1 \mathrm{ml}$ of Folin-Ciocalteau reagent. After 5 minutes, 7\% $\mathrm{Na}_{2} \mathrm{CO}_{3}(10 \mathrm{ml})$ and $10 \mathrm{ml}$ of deionized water were added and mixed thoroughly. Then, the solutionmixture was kept in dark for about 90 minutes at a room temperature and absorbance was taken at $750 \mathrm{~nm}$, against an appropriate blank. Various concentration of gallic acid solution was used for preparation of the standard curve. Total phenolic content was represented as $\mathrm{mg}$ of gallic acid equivalents per gram of the dried leaf sample.

\section{Ultraviolet visible absorption analysis (UV)}

$300 \mathrm{mg}$ of dry leaf powder was placed in $20 \mathrm{ml}$ of Millipore water, kept overnight with continuous stirring at a temperature of $37^{\circ} \mathrm{C}$ and then filtered. A part of the filtered material was scanned from 190-500 nm to detect the distinctive wavelengths by using UV-visible Spectrophotometer (Shimadzu, UV-1800, Japan).

\section{GC/MS analysis of leaf extract}

GC/MS analysis of the aqueous leaf extract of Pergularia daemia was conducted by Gas chromatograph coupled to a mass spectrophotometer equipped with a fused capillary column, (HP-5MS, $0.25 \mathrm{~mm} \times$ $30 \mathrm{~m} \times 0.25 \mu \mathrm{m})$ Model No: Agilent 190915-433. For GC/MS recognition, ionization energy of $69.9 \mathrm{eV}$ was applied to the electron ionization system. The carrier gas was Helium (99\%) with a continuous stream rate of $1 \mathrm{ml} / \mathrm{min}$. The volume of the sample injected was $5 \mu \mathrm{l}$ with GC grade ethanol at an average velocity of $37 \mathrm{~cm} / \mathrm{sec}$. Initial temperature of the column was $50^{\circ} \mathrm{C}$ for 5 min which was then programmed to $280^{\circ} \mathrm{C}$ with the total running time of the GC being 28 minutes.

\section{Experimental animals}

All experimentations with animals were done following "Principles of laboratory animal care" (NIH publication No. 85-23, revised in 1985) and Animal Ethics Guideline issued by Govt. of India in 1995, as well as following specific Indian laws on "Protection of Animals" under the supervision of approved investigators. All animals were housed and in vivo experiments were performed at Animal house facility of Sidho-Kanho-Birsha University, with due permission from Institutional Animal Ethics Committee [IAEC] 
(No 1973/GO/Re/S/17/CPCSEA; Committee for the Purpose of Control and Supervision of Experiments on Animals, Exp No: IAEC/ZOO/SJB-1). The study was conducted on random inbred female albino mice (Mus musculus) whose weight varied between 23 and 28 g. Nearly 30 lactating females having minimum of 5 pups, were selected for the study. Oral acute and sub-acute toxicity studies were conducted following OECD guidelines.

Mice were segregated into 5 groups. Group I was the normal control without any treatment (placebo mice received only water since the leaf extract was dissolved in double distilled water, $60 \mu \mathrm{l}$ ) whereas mice in groups II, III, IV and V received $50 \mathrm{mg} / \mathrm{kg} \mathrm{b}$. wt., $100 \mathrm{mg} / \mathrm{kg}$ b. wt., $150 \mathrm{mg} / \mathrm{kg}$, and $200 \mathrm{mg} / \mathrm{kg} \mathrm{b}$. wt. of leaf extract of PD (aqueous, $60 \mu \mathrm{l}$ ) orally. These doses were selected after conducting acute and subacute toxicity investigations. Dam milk production was measured by a commonly used protocol [23]. In brief, the weights of the pups were taken at $8.00 \mathrm{AM}$ and allocated (W1). Then the pups were kept isolated away from the mother for 6 hours and their weight was taken again which was considered (W2). Then the pups were returned back to their mothers to be fed for 1 hour and subsequently weighed again which was assigned (W3). The daily milk yield was adjusted for the loss of weight caused due to various metabolic processes in the pups. The value considered for the experiment was $\mathrm{W} 2-\mathrm{W} 1 / 6$, the number obtained was multiplied by the number of hours the pups suckled per day and added to the daily suckling gain. The everyday gain in pups' weight was measured from W2. Blood was collected from the tail vein of mice and the serum was isolated and kept in $-20^{\circ} \mathrm{C}$ until further use. At the end of the experiment the mice were administered with a combination of ketamine-dexmedetomidine (intra-peritoneal, the dose $80 \mathrm{mg} / \mathrm{kg}$ of ketamine $+1 \mathrm{mg} / \mathrm{kg}$ dexmedetomidine to induce anaesthesia) and then sacrificed by cervical dislocation.

\section{Prolactin levels}

Serum prolactin levels were analysed by the Tietz method, following manufacturers protocol using Elisa kits (Kruise Pathline, Ahmedabad, India) [24].

\section{Statistical analysis}

Results were given as a mean $\pm \mathrm{SD}$ of each group. One-way ANOVA and Dunnet's test were employed to find the significant difference among groups. A probability of $p<0.05$ was considered to be statistically significant.

\section{RESULTS}

The aqueous extract had $120 \mu \mathrm{g} / \mathrm{ml}$ of total phenolic content and the qualitative assay showed presence of flavonoids, alkaloids, tannin, glycosides, reducing sugars and steroids which are presented in table 1.

Table 1.

Qualitative data on phytoconstituents present in the aqueous leaf extract of Pergularia daemia.

\begin{tabular}{cll}
\hline Sl No & Chemical compounds & Intensity \\
\hline 1. & Flavonoids & ++++ \\
\hline 2. & Alkaloids & +++ \\
\hline 3. & Carbohydrate & ++ \\
\hline 4. & Tannin & + \\
\hline 5. & Reducing sugar & ++ \\
\hline 6. & Glycosides & + \\
\hline 7. & Steroids & +++ \\
\hline 8. & Phenolics & +++ \\
\hline 9. & Carotenoids & ++ \\
\hline
\end{tabular}

+ minute, ++ less abundant, +++ , and ++++ much abundant

Aqueous leaf extract of PD at all four doses showed a dose-dependent suppression of DPPH activity by about 23 to $29 \%$ at concentrations of 400 to $800 \mu \mathrm{g} / \mathrm{ml}$, compared to the standard in figure 1 . UV-Vis spectrophotometric data revealed the presence of 5 major peaks when the aqueous extract was scanned from $190 \mathrm{~nm}$ to $500 \mathrm{~nm}$ and most peaks were between 400 to $500 \mathrm{~nm}$. The major peak we found was between 230 and $300 \mathrm{~nm}$ due to the incidence of flavonoids and phenolic compounds. The flavonoid spectra characteristically consist of two greatest absorptions in ranges of $230-285 \mathrm{~nm}$ (band I) and 300-350 nm (band II), while the absorption maxima in a range of $420 \mathrm{~nm}$ and $444 \mathrm{~nm}$ could be due to $\alpha$-carotene and lutein (tab. 2, fig. 2).

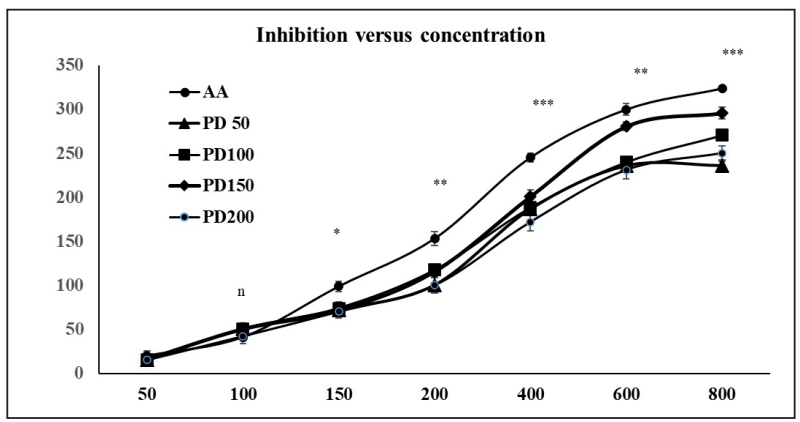

Figure 1.

Figure of percentage inhibition of aqueous leaf extract of Pergularia daemia against standard ascorbic acid (AA). ${ }^{*} p<0.05,{ }^{* *} p<0.01,{ }^{* *} p<0.001, \mathrm{n}-$ non-significant 


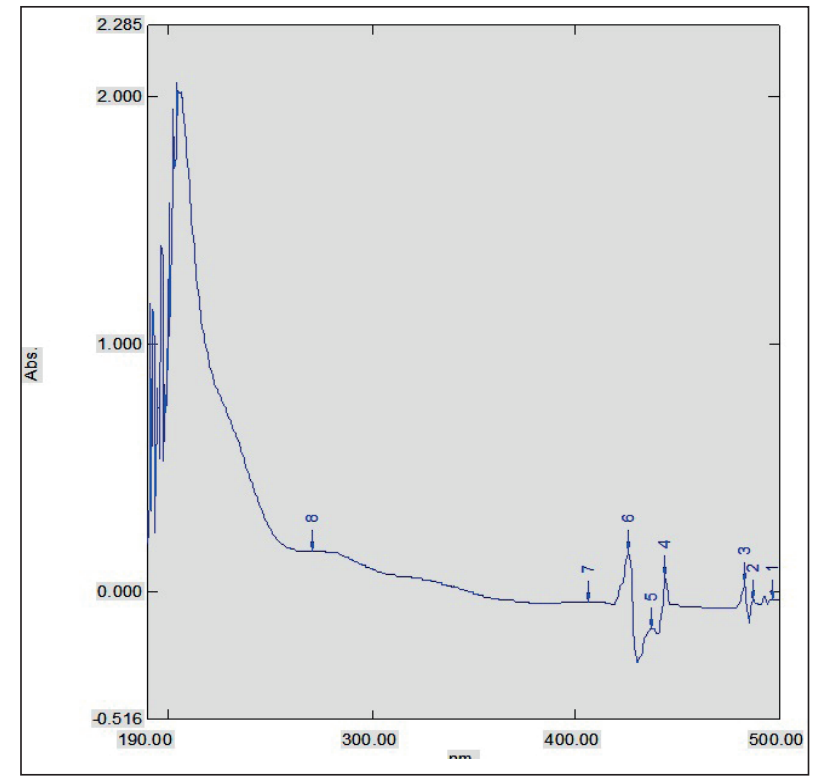

Figure 2.

UV-vis spectrophotometric data of the extract revealing various absorbance and the peaks

Table 2.

Table showing the Uv-vis spectrophotometric data of aqueous extract of Pergularia daemia

\begin{tabular}{cccc}
\hline Sl No & Wavelength & Absorbance & Peak number \\
\hline 1. & 483.00 & 0.037 & 3 \\
\hline 2. & 444.00 & 0.060 & 4 \\
\hline 3. & 426.00 & 0.162 & 6 \\
\hline 4. & 270.50 & 0.164 & 8 \\
\hline 5. & 266.00 & 0.163 & 16 \\
\hline
\end{tabular}

The GC-MS study revealed 16 peaks of various compounds that reportedly act against various ailments. In the present study we found that linoleic acid, ethyl ester, 1-monolinoleoylglycerol trimethylsilyl ether, $\beta$-sitosterol, $\alpha$-amyrin, $\beta$-amyrin and, phytol is present in the extract and they have considerable percentage peak areas and some had large retention time (tab. 3 ).

In the present study, the acute and subacute toxicity studies revealed no death after 96 hours of treatment while one mortality was reported after 30 days of treatment (tab. 4). Acute and subacute toxicity studies revealed that even at higher doses, aqueous leaf extract of PD was relatively non-toxic to mice, as they all survived. Neither their weight decreased nor did they reveal any toxic symptoms (tab. 4). However, administration of the leaf extract at $400 \mathrm{mg} / \mathrm{kg}$ and $500 \mathrm{mg} / \mathrm{kg}$ revealed minor salivation, occasional corner sitting, increased sniffing, and drowsiness which were noted on the table side observation of the animals. Based on these studies, doses of $50 \mathrm{mg} / \mathrm{kg}, 100 \mathrm{mg} / \mathrm{kg}, 150 \mathrm{mg} / \mathrm{kg}$ and $200 \mathrm{mg} / \mathrm{kg}$ body weight were selected for subsequent galactagogic studies.

When the lactating female mice were administered with various doses of aqueous leaf extract it was found that 150 and $200 \mathrm{mg} / \mathrm{kg}$ body weight of PD leaf extract showed a considerable increase in milk production when compared to normal lactating mice from the $3^{\text {rd }}$ to $10^{\text {th }}$ day which was statistically significant $(p<0.05$ through $p<0.01)$. Furthermore, when the group taking $150 \mathrm{mg} / \mathrm{kg}$ b. wt.

Table 3.

GC-MS analysis of the extract of Pergularia daemia showing different phytoconstituents

\begin{tabular}{|c|c|c|c|c|c|}
\hline No & RT & Name of compound & Mol. Formula & Mol. weight & Peak area $[\%]$ \\
\hline 1 & 8.04 & trans-13-Octadecenoic acid & $\mathrm{C}_{18} \mathrm{H}_{34} \mathrm{O}_{2}$ & 282 & 0.51 \\
\hline 2 & 8.56 & 2-Hexadecanol & $\mathrm{C}_{16} \mathrm{H}_{34} \mathrm{O}$ & 242 & 1.6 \\
\hline 3 & 8.71 & 9-Hexadecenoic acid & $\mathrm{C}_{16} \mathrm{H}_{30} \mathrm{O}_{2}$ & 254 & 0.57 \\
\hline 4 & 10.17 & 2-Pentanone & $\mathrm{C}_{9} \mathrm{H}_{18} \mathrm{O}$ & 142 & 0.29 \\
\hline 5 & 11.03 & Diethypthallate & $\mathrm{C}_{12} \mathrm{H}_{14} \mathrm{O}_{4}$ & 222 & 2.84 \\
\hline 6 & 11.35 & 9-Tetradecenoic acid & $\mathrm{C}_{14} \mathrm{H}_{26} \mathrm{O}_{2}$ & 226 & 0.63 \\
\hline 7 & 13.44 & Cyclopropanetetradecenoic acid & $\mathrm{C}_{26} \mathrm{H}_{50} \mathrm{O}_{2}$ & 394 & 1.47 \\
\hline 8 & 13.57 & 2,3-Dihydroxypropyl elaidate & $\mathrm{C}_{21} \mathrm{H}_{40} \mathrm{O}_{4}$ & 356 & 0.84 \\
\hline 9 & 16.04 & Coumatetralyl isomer & $\mathrm{C}_{20} \mathrm{H}_{18} \mathrm{O}_{3}$ & 306 & 4.48 \\
\hline 10 & 16.81 & 4-Oxazolecarboxylic acid, 4,5-dihydro-2-phenyl-1-methylethyl ester & $\mathrm{C}_{13} \mathrm{H}_{15} \mathrm{NO}_{3}$ & 233 & 11.85 \\
\hline 11 & 17.02 & Linoleic acid ethyl ester & $\mathrm{C}_{20} \mathrm{H}_{36} \mathrm{O}_{2}$ & 308 & 2.02 \\
\hline 12 & 35.58 & 1-Monolinoleoylglycerol trimethylsilyl ether & $\mathrm{C}_{27} \mathrm{H}_{54} \mathrm{O}_{4} \mathrm{Si}_{2}$ & 498 & 1.85 \\
\hline 13 & 37.25 & $\beta$-Sitosterol & $\mathrm{C}_{29} \mathrm{H}_{50} \mathrm{O}$ & 414 & 1.47 \\
\hline 14 & 37.42 & $\alpha$-Amyrin & $\mathrm{C}_{30} \mathrm{H}_{50} \mathrm{O}$ & 426 & 0.51 \\
\hline 15 & 38.27 & $\beta$-Amyrin & $\mathrm{C}_{30} \mathrm{H}_{50} \mathrm{O}$ & 426 & 0.36 \\
\hline 16 & 52.16 & Phytol & $\mathrm{C}_{20} \mathrm{H}_{40} \mathrm{O}$ & 296 & 7.17 \\
\hline
\end{tabular}


Table 4.

Showing acute and sub-acute toxicity studies, mortality and symptoms of mice treated with various concentration of aqueous extract of Pergularia daemia

\begin{tabular}{cccc}
\hline Sl No & Dose/day & Mortality & Symptoms after administration of PD \\
\hline \multicolumn{5}{c}{} & \multicolumn{3}{c}{ Acute toxicity $(96 \mathrm{hr})$} \\
\hline 2 & $25 \mathrm{mg} / \mathrm{kg}$ & $0 / 6$ & $\mathrm{Nil}$ \\
\hline 3 & $50 \mathrm{mg} / \mathrm{kg}$ & $0 / 6$ & Nil \\
\hline 4 & $100 \mathrm{mg} / \mathrm{kg}$ & $0 / 6$ & $\mathrm{Nil}$ \\
\hline & $200 \mathrm{mg} / \mathrm{kg}$ & $0 / 6$ & Nil \\
\hline 5 & & & Sub-acute toxicity (30 days) \\
\hline 6 & $500 \mathrm{mg} / \mathrm{kg}$ & $0 / 6$ & corner sitting, sniffing \\
\hline
\end{tabular}

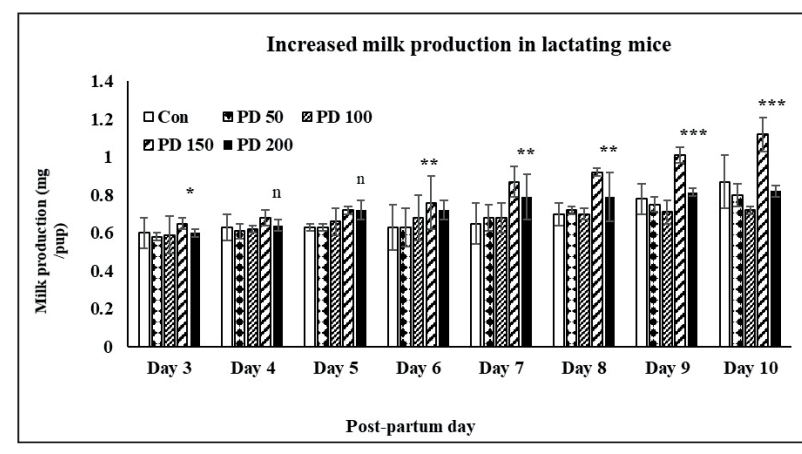

Figure 3.

Effect of aqueous extract of Pergularia daemia on milk production (mg/pup). ${ }^{*} p<0.05,{ }^{* *} p<0.01,{ }^{* *} p<0.001$, $\mathrm{n}-$ non-significant

was compared with the dams fed with 50,100 , and $200 \mathrm{mg} / \mathrm{kg}$ bodyweight of aqueous leaf extract it revealed that milk production improved which was also statistically significant $(p<0.01)$. Doses of $50 \mathrm{mg} / \mathrm{kg}$ and $100 \mathrm{mg} / \mathrm{kg}$ b. wt. of the leaf extract did not improve milk production performance compared to the normal control (fig. 4).

Similarly, a slow increase in weight was observed in pups from the initial days at all fixation intervals but the results were statistically significant on the $12^{\text {th }}, 13^{\text {th }}, 14^{\text {th }}$ and $15^{\text {th }}$ day in groups of mice fed with 150 and $200 \mathrm{mg} / \mathrm{kg}$ body weight of PD leaf extract compared to suitable control $(p<0.05)$ and groups fed with 50 and $100 \mathrm{mg} / \mathrm{kg}$ of aqueous leaf extract (fig. 4).

When the variation in serum prolactin levels was compared between treated and control sets of mice, it revealed that PD leaf extract at a dose of $150 \mathrm{mg} / \mathrm{kg}$ showed the highest concentration in blood from $2^{\text {nd }}$ to $12^{\text {th }}$ day. Lactating mothers administered with $200 \mathrm{mg} / \mathrm{kg}$ of extract also showed an increase of

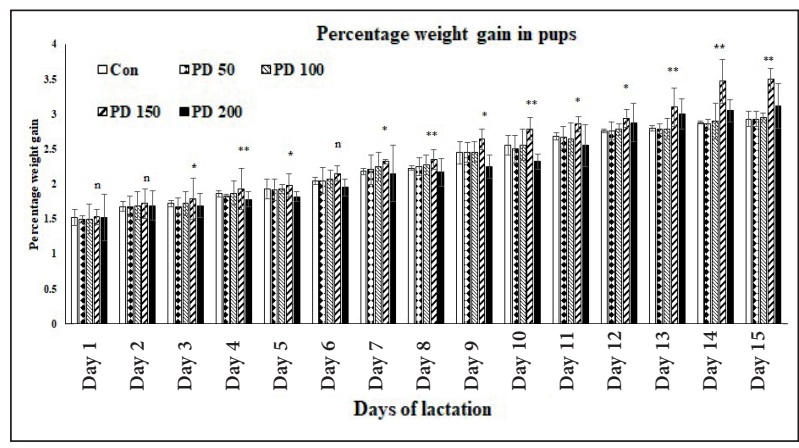

Figure 4.

Figure represents percentage weight gain in pups in different treated and control sets from day 1 to day 15 treated with various doses of Pergularia daemia (PD). ${ }^{\star} p<0.05,{ }^{* *} p<0.01,{ }^{* * *} p<0.001, \mathrm{n}-$ non-significant

prolactin content from $6^{\text {th }}$ to $8^{\text {th }}$ day. However, this decreased on the $10^{\text {th }}$ to $12^{\text {th }}$ day when compared to normal control $(p<0.05)$. The other two doses did not show any increase compared to the normal control mothers (fig. 5). However, we were unable to

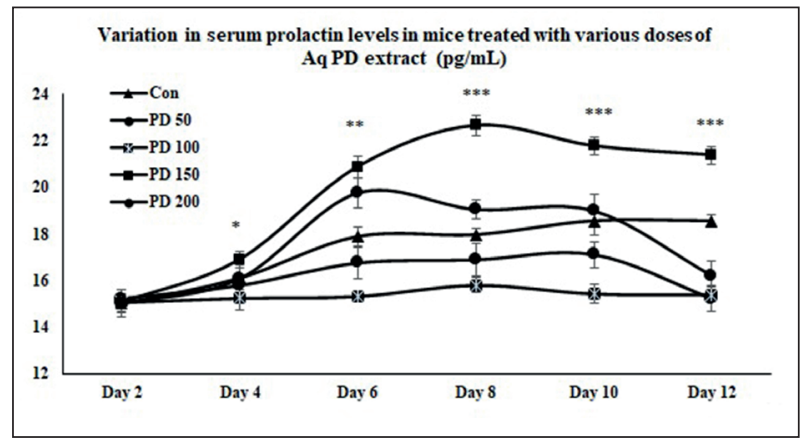

Figure 5.

Serum prolactin level $(\mathrm{pg} / \mathrm{ml})$ variation in mice treated with various doses of Pergularia daemia (PD), ${ }^{\star} p<0.05$, ${ }^{* *} p<0.01,{ }^{* * *} p<0.001$ 
analyse serum prolactin levels for a few more days due to low serum levels and as we felt that regular drawing of blood might harm both the dam and pups.

\section{DISCUSSION}

In India, a substantial part of the population still lives in tribal areas and depends solely on quacks and traditional healers for primary healthcare. Often tribal healers administer their farm animals and tribal people with plant parts to increase milk production. There is limited data on such galactagogues regarding their safety and efficacy. There are reports that milk production increases due to tactile stimulation which is sufficient to raise the blood oxytocin levels above the threshold limit $[25,26]$. Inadequate milk supply is one of the important problems that lactating mothers face, hence, herbs have been routinely used to increase lactation, which is prevalent even today among various tribal populations. Their use is primarily based on prior understanding and practice. There are only limited investigations that effectively demonstrate the galactagogic properties of herbs, their safety, and effectiveness. Throughout the world women have used many approaches to increase milk production such as special diets, and use of herbal or natural substances. Mothers of different social and traditional backgrounds often choose various methods for the purpose according to their tradition or experience $[27,28]$. Some investigators reported that few herb aids in lactation are Trigonella foenum-graecum [29, 30], Cnicus benedictus [31], Silybum marianum [32, 33], Galega officinalis $[34,35]$, Althaea officinalis [36, 37], Camellia sinensis [38] and Nigella sativa [39]. Many of these herbal medicines have gained popularity in the Western and other Asian countries as galactagogues. In our study, the increase of milk production in lactating mice might be due to proliferation and activity of mammary epithelial cells which in turn is due to the action of the extract on mammary glands and hormones involving in lactation like prolactin [40-42].

We also found that there were some complexes with potent antioxidant properties and are phyto-estrogenic in nature, such as $\beta$-sitosterol. PD contains several phytochemical compounds such as steroids, triterpenoids, tannins, flavonoids, coumarins, and reducing sugars which explains its utilization in traditional medicine. Toxicity studies revealed that the water extract of the plant is virtually non-toxic and harmless for use when administered orally even at higher doses such as $400 \mathrm{mg} / \mathrm{kg}$ and $500 \mathrm{mg} / \mathrm{kg}$ for 30 days. Others have also reported that flavonoids, alkaloids, saponins, and tannins are responsible for the galactagogic activity and their activity decreases the dopamine antagonist, a competitive PRL antagonist. Therefore, inhibition of dopamine synthesis may increase milk production in the rodents.

In the present study the plant showed strong antioxidant activity which may be due to the occurrence of several phytoconstituents that appeared in the GC-MS study, such as phytol, hexadecenoic acid, tetra-decenoic acid, etc. Furthermore, the existence of phenols, carotenoids, and flavonoids may be accountable for the augmentation of antioxidant activity proven in the qualitative assays used in the present study. Our outcomes show that secretion of prolactin plays a key role in lactation. Milk production was significantly increased in mice treated with aqueous leaf extract in various doses compared to untreated control. The upsurge in milk production in lactating mice could be due to the increased production/proliferation of cells present in the mammary glands. Milk ingestion is responsible for the physiological development of new-born pups and the surge in body weight observed in pups revealed that aqueous extract in various doses could be helpful. However, pups of the dams getting a dose of $150 \mathrm{mg} / \mathrm{kg}$ body weight of aqueous extract increased weight significantly when linked to the other three doses and the control $(p<0.001)$. The percentage weight gain in pups was strongly co-related to the quantity of the milk available when they were being suckled which was also more in the group which received $150 \mathrm{mg} / \mathrm{kg}$ aqueous extract in the present investigation. Furthermore, phyto-estrogenic compounds such as $\beta$-sitosterol could also be responsible for the formation of the oestrogen hormone which helps in developing milk ducts, alveoli of mammary glands and also increases the concentration of oestrogen receptors [24]. The existence of numerous compounds in the present study such as phytol (derivative of chlorophyll), hexadecenoic acid (palmitic acid), octadecanoic acid (stearic acid), and flavonoids might be responsible for the galactagogic properties owing to the action of a single compound or conjoint action of all compounds. Investigation conducted by other investigators also put forward that some of the phytoconstituents are accountable for increased milk yield in farm animals which is also in line with our findings [43-48]. Further research is required on mouse mammary cell lines and in other mammalian models to come to a definite conclusion. Our investigation suggests that aqueous 
PD leaf extract has the potential for use as a galactagogue and can raise confidence regarding its safety and efficacy.

\section{ACKNOWLEDGEMENTS}

The authors sincerely acknowledge DST-Govt. of West Bengal for financial support [261(Sanc./ST/P/ S\&T/1G-59/2017] and to and the Department of Science and Technology, Govt. of India, DST-FIST (SR/FST/LS-I/2018/173) as also DBT-BOOST No. $118 / 14 / \mathrm{BT}$ (Estt)/1P-4/2013 for providing the necessary infrastructural support.

Conflict of interest: Authors declare no conflict of interest.

\section{REFERENCES}

1. Gabay MP. Galactogogues: medications that induce lactation. J Hum Lact 2002; 18(3):274-279. doi: http://dx.doi.org/10.1177/089033440201800311

2. Hale TW, Hartmann PE. Hale\& Hartmann's Textbook of Human Lactation. Hale Publishing 2007 LP $1^{\text {st }}$ ed.; Amarillo, Texas, USA.

3. Bruckmaier RM, Wellnitz O. Induction of milk ejection and milk removal in different production systems. J AnimSci 2008; 85:15-20. doi: http://dx.doi.org/10.2527/jas.2007-0335

4. Brodribb W. ABM Clinical Protocol \#9, Use of galactagogues in initiating or augmenting maternal milk production, second revision, Breastfeed Med 2018; 13:307-314.

5. Mortel M, Mehta SD. Systematic review of the efficacy of herbal galactagogues. J Hum Lact 2013; 29(2):154-162. doi: http://dx.doi. org/10.1177/0890334413477243

6. Jackson PC. Complementary and alternative methods of increasing breast milk supply for lactating mothers of infants in the NICU. Neonatal Netw 2010; 29(4):225-230. doi: http://dx.doi. org/.1891/0730-0832.29.4.225

7. Hardy ML. Herbs of special interest to women. J Am Pharm Assoc 2000; 40(2): 234-242. doi: http:// dx.doi.org/10.1016/s1086-5802(16)31064-6
8. Bnouham M. Medical plants with potential galactagogue activity in the Moroccan Pharmacopoeia. J Complement Integr Med 2010; 7(1). doi: http://dx.doi.org/10.2202/1553-3840.1268

9. Satish CJ, Sharma RA, Jain R, Macalo N, Capasso F, Vijayvergia R. Ethnopharmacological evaluation of P. daemia (Forssk.) Chiov. Phytother Res 1998 ; $12: 378-380$.

10. Suresh Kumar SV, Mishra SH. Hepato protective effect of extracts of Pergularia daemia (Forssk.). J Ethnopharmacol 2006; 107:164-168. doi: http:// dx.doi.org/10.1016/j.jep.2006.02.019

11. Sadik G, Gafur MA, Bhuiyan MSA, Khurshid Alam AHM, Biswas MHU, Hassan P et al. Antifertility activity of Pergularia daemia. J Med. Sci 2001; 1:22-24. doi: http://dx.doi.org/10.3923/ jms.2001.22.24

12. Wahi AK, Ravi J, Hemalatha S, Singh PN. Antidiabetic activity of Daemia extensa. J Nat Remed 2002; 2(1):80-83. doi: http://dx.doi.org/10.18311/ jnr/2002/350

13. Senthilkumar M, Gurumoorthi P, Janardhanan K. Antibacterial potential of some plants used by tribals in Muruthamalai hills, Tamil Nadu. Nat Prod Rad 2005; 4:27-34.

14. Hukkeri VI, Patil MB, Jabalpure SS, Ali A. Antiinflammatory activity of various extracts of Pergularia extensa NEBR (Asclepiadaceae). Indian J Pharmaceutical Sci 2001; 63:429-431.

15. Kumar B, Yadav DK, Govindarajan R, Pushpangadan P. Wound healing activity of Pergularia daemia (Forssk.) Chiov. Pharmacog Ethno Pharmacol 2006; 1:12-14.

16. Raghavamma STV, Rama Rao N, Devala Rao G. Inhibitory potential of important phytochemicals from Pergularia daemia (Forssk.) Chiov., on snake venom (Naja naja). J Genet Eng Biotechnol 2016; 14(1):211-217. doi: http://dx.doi. org/10.1016/j.jgeb.2015.11.002

17. Ananth DA, Rameshkumar A, Jayadevi R, Aseervatham GSB, Sripriya J, Bose PC, Sivasudha T. Amelioratory effect of flavonoids rich Pegularia daemia extract against CFA induced arthritic rats. Bio Pharm 2016; 80:244-252. doi: http:// dx.doi.org/10.1016/j.biopha.2016.03.019 
18. Anjaneyulu ASN, Raju DVSN, Srinivasa, Rao S. Chemical evaluation of $P$. daemia. Indian J Chem 1998; 37B:318-320.

19. Vaithiyanathan V, Mirunalini S. Quantitative variation of bioactive phyto-compounds in eth$\mathrm{yl}$ acetate and methanol extracts of Pergularia daemia (Forssk.) Chiov. J Biomed Res 2015; 29(2):169-172. doi: http://dx.doi.org/10.7555/ JBR.28.20140100

20. Bhaskar VH, Balakrishnan N. Pharmacognostic studies on Pergularia daemia roots. Pharm Biol 2010; 48(4):427-432. doi: http://dx.doi. org/10.3109/13880200903160699

21. Braca A, Sortino C, Politi M. Anti-oxidant activity of flavonoids from Licanialicaniae flora. J Ethnopharmacol 2002; 79:379-381. doi: http:// dx.doi.org/10.1016/s0378-8741(01)00413-5

22. Kim DO, Jeong SW, Lee CY. Anti-oxidant capacity of phenolic phytochemicals from various cultivars of plums. Food Chem 2003; 81:321326. doi: http://dx.doi.org/10.1016/S03088146(02)00423-5

23. Lompo-Ouedraogo Z, van der Heide D, Van der Beek EM, Swarts HJ, Mattheij JA, Sawadogo L. Effect of aqueous extract of Acacia nilotica ssp adansonii on milk production and prolactin release in the rat. J Endocrinol 2004; 182(2):257-266. doi: http://dx.doi.org/10.1677/joe.0.1820257

24. Tietz NW. Clinical Guide to Laboratory Tests. 3rd Ed. Philadelphia: WB Saunders. Co. 1995.

25. Bruckmaier RM, Schams D, Blum JW. Continuously elevated concentrations of oxytocin during milking are necessary for complete milk removal in dairy cows. J Dairy Res 1994; 61(3):323-334. doi: http://dx.doi.org/10.1017/ s0022029900030740

26. Weiss D, Dzidic A, Bruckmaier RM. Effect of stimulation intensity on oxytocin release before, during and after machine milking. J Dairy Res 2003; 70(3):349-354. doi: http://dx.doi. org/10.1017/S0022029903006216

27. Ayers JF. The use of alternative therapies in the support of breast feeding. J Hum Lact 2000; 16:52-56. doi: http://dx.doi. org/10.1177/089033440001600111
28. Low Dog T. The use of botanicals during pregnancy and lactation. Altern Ther Health Med 2009; 15:54-58.

29. Damanik R, Wahlqvist ML, Wattanapenpaiboon N. Lactagogue effects of Torbangun, a Bataknese traditional cuisine. Asia Pac J ClinNutr 2006; 15(2):267-274.

30. Khan TM, Wu DB, Dolzhenko AV. Effectiveness of fenugreek as a galactagogue: A network metaanalysis. Phytother Res 2018; 32(3):402-412. doi: http://dx.doi.org/10.1002/ptr.5972

31. Zuppa AA, Sindico P, Orchi C, Carducci C, Cardiello V, Romagnoli C, Catenazzi P. Safety and efficacy of galactagogues: substances that induce, maintain and increase breast milk production. J Pharm Pharm Sci 2010; 13(2):162-174. doi: http://dx.doi.org/10.18433/J3DS3R

32. Di Pierro F, Callegari A, Carotenuto D, Tapia MM. Clinical efficacy, safetyand tolerability of BIO-C (micronized Silymarin) as a galactagogue. Acta Biomed 2008; 79(3):205-210

33. Capasso R, Aviello G, Capasso F, Savino F, Izzo AA, Lembo F, Borrelli F. Silymarin BIO-C, an extract from Silybum marianum fruits, induces hyper-prolactinemia in intact female rats. Phytomed 2009; 16(9):839-844. doi: http://dx.doi. org/10.1016/j.phymed.2009.02.007

34. Keeler RF, Baker DC, Evans JO. Individual animal susceptibility and its relationship to induced adaptation or tolerance in sheep to Galega officinalis. L. Vet Hum Toxicol 1988; 30(5):420-423.

35. Salatino S, Giacomelli L, Carnevali I, Giacomelli E. The role of natural galactagogues during breast feeding: focus on a Galega officinalis based food supplement. Minerva Pediatr 2017; 69(6): 531-537. doi: http://dx.doi.org/10.23736/S00264946.16.04797-6

36. Sim TF, Hattingh HL, Sherriff J, Tee LB. The use, perceived effectiveness and safety of herbal galactagogues during breast feeding: A Qualitative Study. Int J Environ Res Public Health 2015; 12(9):11050-11071. doi: http://dx.doi. org/10.3390/ijerph 120911050

37. Rahnemaie FS, Zare E, Zaheri F, Abdi F. Effects of complementary medicine on successful breast 
feeding and its associated issues in the postpartum period. Iran J Pediatr 2018; 29(1):e80180. doi: http://dx.doi.org/10.5812/ijp.80180

38. Kavurt S, Bas AY, Aydemir O, Yucel H, Isikoglu $\mathrm{S}$, Demirel N. The effect of galactagouge herbal tea on oxidant and anti-oxidant status of human milk. J Matern Fetal Neonatal Med 2013; 26(10): 1048-1051

39. Hosseinzadeh H, Tafaghodi M, Mosavi MJ, Taghiabadi E. Effect of aqueous and ethanolic extracts of Nigella sativa seeds on milk production in rat. J Acupunct Meridian Stud 2013; 6(1):18-23. doi: http://dx.doi.org/10.1016/j.jams.2012.07.019

40. Javan R, Javadi B, Feyzabadi Z. Breastfeeding: A review of its physiology and galactagogue plants in view of traditional Persian medicine. Breastfeed Med 2017; 12(7): 401-409. doi: http://dx.doi. org/10.1089/ bfm.2017.0038

41. Silva F, Dias F, Costa G, Campos MGD. Chamomile reveals to be a potent galactagogue: The unexpected effect. J Matern Fetal Neonatal Med 2017; 10:1-3. doi: http://dx.doi.org/10.1080/1476 7058.2016.1274300

42. Kent JC, Prime DK, Garbin CP. Principles for maintaining or increasing breast milk production. J Obstet Gynecol Neonatal Nurs 2012; 41:114-121. doi: http://dx.doi.org/10.1111/ j.1552-6909.2011.01313.x

43. Koko BK, Konan AB, Kouacou FKA, Djètouan JMK, Amonkan AK. Galactagogue effect of $E$ uphorbia hista (Euphorbiaceae) aqueous leaf extract on milk production in female Wistar rats. J Bioscience Med 2019; 7:51-65. doi: http://dx.doi. org/10.4236/jbm.2019.79006
44. Sevrin T, Alexandre-Gouabau MC, Castellano B, Aguesse A, Ouguerram K, Ngyuen P et al. Impact of fenugreek on milk production in rodent models of lactation challenge. Nutrients 2019. doi: http://dx.doi.org/10.3390/nu11112571

45. Gaya I, Mohammad O, Suleiman A, Maje M, Adekunle A. Toxicological and lactogenic studies on the seeds of Hibiscus sabdariffa Linn. (Malvaceae) extract on serum prolactin levels of albino Wistar rats. The Internet J Endocrinol 2008. doi: http://dx.doi.org/doi.org/10.5580/26b5

46. Piantoni P, Lock AL, Allen MS. Palmitic acid increased yields of milk and milk fat and nutrient digestibility across production level of lactating cows. J Dairy Sci 2013; 96(11): 7143-7154.

47. Li M, Hassan FU, Tang Z, Peng L, Liang X, Li L et al. Plant flavonoids to improve productivity of ruminants - A review. Anim Feed Sci Technol 2019; 251:21-36.

48. Burch AM, Pineda A, Lock AL. Effect of palmitic acid-enriched supplements containing stearic or oleic acid on nutrient digestibility and milk production of low- and high-producing dairy cows. J Dairy Sci 2021; 104(8):8673-8684. doi: http:// dx.doi.org/10.3168/jds.2020-19913 